\title{
Perceptions on Project-Based Assessment Rubrics: A Rubric Design for Indonesian School Contexts
}

\author{
Dr. Fadly Azhar \\ English Department Faculty of Education \& Teacher Training (FKIP) University of Riau, \\ Kampus Binawidya, Pekanbaru, Indonesia \\ Email: fadlyazhar57@gmail.com
}

\section{Doi:10.5901/mjss.2015.v6n4s3p463}

\begin{abstract}
This research aimed at finding out the perceptions of English teaching staff (ETS) of FKIPUR, FKIPUIR, FTUIN Susqa, and state secondary schools in Pekanbaru, Indonesia towards a project-based assessment rubric viewed from the aspects of content, organization, and language (COL). Perceptions in this context dealt with two aspects; namely, the accuracy and the practicality of various constructs included in a project-based assessment rubric. The research findings showed that all ETS had high level of perceptions on the aspect of accuracy (3.84 - 4.10); however, they had moderate level of perceptions on the constructs of format, critical instructions \& activities to do, and interval in terms practicalities (3.48 - 3.66). Qualitatively, the aspects of language should not be assessed in more detail; and capitalization along with punctuation should be linked with writing mechanics. Finally, hypothesis testing showed that there was no significant difference in ETS' perceptions toward the project-based assessment rubric viewed from the variants of institutions, fields of study, academic qualifications, teaching experience, and training.
\end{abstract}

Keywords: perception, project-based assessment rubric, content, organization, language

\section{Introduction}

Constructing an assessment rubric including the project-based assessment rubric is one of major problems in educational contexts. In Indonesia, for example, Media Informasi Online Stikom (2003) in Edy Supriyadi (2007) stated that teachers in Indonesia had a low level skill in designing and implementing classroom-based assessments including their rubrics. One reason is due to the low frequency of related training on assessments for teachers. In line with this, Depdiknas (2003) reported that teachers in thirty-two provinces in Indonesia had a low skill in designing classroom-based assessments such as performance, project, and product that need special rubrics. One of the reasons for this was that teachers had a tendency using such written objective tests as multiple-choice, true false, and matching.

In line with this, Birgin \& Baki (2009) stated that teachers in Turkey faced a significant inhibition in constructing assessment rubrics. This is due to the fact that this activity is a new evaluation method for teachers in Turkey. In addition, Moskal \& Jon (2000) assumed that various constructs in a rubric must be valid and reliable since it has an important role for the evaluation and measurement of students' performance, project, and product. Tierney \& Marielle (2004) explained that many of rubrics available in various sources did not function properly because of inconsistency in terms of expected criteria of descriptions. In other words, it is quite hard to construct even to obtain rubrics of performance, project, or product-based assessments that are eligible, suitable, feasible, proper, and fit with the needs of assessors, raters and evaluators.

In relation to these phenomena, Fadly Azhar (2013) has designed a set of rubric for the evaluation and measurement of project-based assessment containing the aspects of content, organization, language (COL) and it is grouped into two factors: accuracy and practicality. The factor of accuracy refers to whether or not all of constructs in that rubric are able to evaluate and measure a project accurately while the factor of practicality is concerned with whether or not the rubric is simple enough in terms of implementation. This project-based assessment rubric was officially presented in an annual seminar for the state universities of western part of Indonesia conducted by State Islamic Institute Pontianak, West Kalimantan, Indonesia (August, 2013).

In conjunction with evaluation and measurement, Hughes (2003), Shohamy (1985), Hutchinson \& Young (2011), Fernandes (1984), Dickens \& Germaine, (1992), Crooks, (2011), O'Malley \& Pierce (1996), Popham, (1995), Ariev, (2005), Brooks, (2002), Brown, (2004), Mertler, (2001), McMillan, (2004), and Weigle (2002) stated that project-based assessment rubric can be defined as a set of rubric containing valid and reliable aspects for the evaluation and 
measurement of scientific paper writing. Hence, such aspects as content, organization, and language should be the first priority in the construction of project-based assessment rubric. This is due to the fact that if a project is presented in the form of scientific writing, it will normally and logically have a coverage area in content, organization, and language (COL).

The aspect of content evaluates and measures the purpose and the quality of writing the project viewed from the categories of being scientific, academic, and accurate with the instructions given. To achieve these three categories, Schlegel (1992) introduces nineteen operational verbs known as critical instructions \& activities to do in project writing as in the following:

$>$ Compare (Look for similarities and differences between the things mentioned);

$>$ Contrast (Stress the dissimilarities);

$>$ Criticize (Make your judgment about the item in question. Stress the deficiencies;

$>$ Define (Give a concise and accurate definition);

$>$ Describe (Mention the chief characteristics of a situation or retell the essential features of a story);

$>$ Diagram (Provide a drawing, chart or plan);

$>$ Discuss (Be analytical. Give reasons pro and con. Give the issue some thought and provide an opinion);

$>$ Evaluate (Provide both positive and negative sides of the topic. Assess the subject);

$>$ Explain (Give reasons for what is asked of you. Provide the causes. (e.g. Explain the reason for the Greenhouse effect.);

> Illustrate (Use examples, or where appropriate, provide a diagram or figure);

$>$ Interpret (Translate, solve, or comment on a subject, usually giving your judgment about it);

$>$ Justify (Provide the reasons for your conclusions or for the statement made in the question);

$>$ List (Provide an itemized list. The items should be numbered);

$>$ Outline (Organize your answer into the main points and subordinate points. While it is not necessary that your answer be in outline form it helps to prepare it that way);

$>$ Prove (Provide factual evidence or where appropriate, a logical or mathematical proof);

$>$ Relate (Show the connection between the things mentioned in the question. Note this does not mean to compare, so if you are asked to relate the British and Australian Constitutions, you are not to compare them but to show them how one influences the other);

$>$ Review (Provide a summary, usually a critical one. A review usually also implies commenting on important aspects of the question);

$>$ Summarize (Provide a summary, usually without comment or criticism);

$>$ Trace (Describe the progress of some historical event or where it is appropriate, describe the causes of some event.

For example, students are exposed to the following thesis statement (taken from IELTS Practice Topics, 2006). They are also asked to develop that thesis statement in an essay.

"Some parents grow their children in strict discipline while others leave them free to learn lessons of lives on their own".

There will be three probable ways to expand this thesis statement, namely, (a) to explain growing children in strict discipline, (b) to explain leaving children free to learn lessons of lives on their own, and (c) to compare the two ways of growing children. Out of these three ways, of course, point (c) is much better than those of points (a) and (b). It means that the selection of the verb to compare in terms of critical instructions \& activities to do is much more accurate than that of to explain. This is due to the fact that to compare has more meaningful and more precious information to share.

In order to evaluate and measure the organization of writing skill, Callaghan \& Rothery, (1988), Oshima \& Hogue, (1999), Stanley, (1983) proposed two major concepts: paragraph organization and essay organization. A good paragraph is supposed to cover three sub-elements: topic sentence, supporting sentences, and a concluding sentence. In addition, a paragraph should reflect the elements of unity, coherence, and cohesion. Unlike a paragraph, in essay organization, three components are required; that is, introductory paragraph, main/body paragraphs, concluding paragraph, sentence and paragraph connectors along with writing mechanics.

However, the constructs included in the aspect of organization in this research are focused on text types known as genres. It is undeniable that to be good at writing genres is one of the major aims to be achieved in the learning of English in Indonesian school contexts (Depdiknas, 2008; Kemendikbud, 2013). Through genres, students are expected to be able to write such following texts as descriptive, narrative, procedure, news items, recount, expository, hortatory, short functional texts like invitations, announcements, recipes, manuals, and directions. In short, the evaluation and measurement of the organization aspect should cover two things: accuracy on paragraph organization and generic 
structures of genres.

Similarly, to evaluate and measure the aspect of language ten grammatical elements should be considered, i.e. subject-verb agreement, tense-form, subordination, verbal, pronoun-reference, word form, word order, parallel structure, unnecessary repetition, and correct usage (Stanley, 1983). The reason for choosing these ten elements as the constructs to be included in the rubric is that they tend to occur in each time to write essay writing.

Furthermore, the term of perception in this research, deals with observation, opinion, view, belief, conviction, persuasion, and sentiment. Opinion deals with conclusion; view deals with subjective opinion; belief relates to having a tendency to accept attitude; conviction draws a serious belief; persuasion is relevant to sense of certainty; and sentiment shows either positive or negative reaction (Bernhardt, 2014). Therefore, through this sort of survey of perception, it is really possible to identify the opinion, view, belief, conviction, persuasion, and sentiment of English teaching staff along with English teachers of state secondary schools in Pekanbaru, Indonesia towards the design of project-based assessment rubrics.

\section{Research Problems}

In line with this concept of $\mathrm{COL}$, the research problems are as in the following (a) How good is the perception of the teaching staff of FKIPUR, FKIPUIR, FTUIN Susqa, and state secondary schools on project-based assessment rubric containing COL viewed from the factors of accuracy and practicality? (b) Is there any significant difference on their perception viewed from the variables of institution, field of study, academic qualification, teaching experience, and training?

\section{Research Objectives}

The objective of this sort of survey research is to prove the perception of the teaching staff of FKIPUR, FKIPUIR, FTUIN Susqa, and state secondary schools on project-based assessment rubric containing COL quantitatively and qualitatively. Quantitative aspect in this context concerns with the perception of the teaching staff based on their knowledge, attitude, and skill in project-based assessment rubric; meanwhile qualitative aspect is related to their input and comment about that rubric.

\section{Research Methodology}

This survey research described the object of the research both quantitatively and qualitatively (Arikunto, 2010; Creswell, 2005). In this context, the described object was various constructs provided in a COL-based rubric. A set of questionnaire and a set of open-ended question were the main instruments in this research. The questionnaire contained four major factors: (a) Respondent profile, (b) The perceptions toward the rubric based on their knowledge, attitude, and skill in terms of the factor of accuracy, (c) The perceptions toward the rubric based on the process of implementation in terms of the factor of practicality, (d) qualitative information concerns with (i) comment and input on the rubric based on their knowledge, attitude, skill and (ii) other aspects to be included into the rubric. The data obtained from part (a), (b), and (c) was analyzed with a table of mean score interpretation as in the following: 1.0002 .33 (low), 2.34 - 3.66 (moderate), and $3.67-5.00$ (high) (Erman \& Yaya, 1990) and inferential statistic (Sugiyono, 2011). Meanwhile, part (d) was analyzed with focus group discussion program (Krueger, 1994).

The questionnaires were sent to one hundred teaching staff of English Study Program of FKIPUR, FKIPUIR, FTUIN Susqa, and state secondary schools in Pekanbaru, Indonesia. However, only seventy-five of them returned the questionnaires. Therefore, all of them were taken as the sample of this research (total sampling). In terms of academic qualification, the sample respondents consisted of 38 (51\%) Bachelors, 30 (40\%) Masters, and only 7 (9\%) Doctors. For the field of study, 58 (77\%) of them are in English education, 7 (9\%) in literatures, 7 (9\%) in linguistics, 1 (4\%) of each in curriculum development, educational technology, and social science/culture. Finally, in terms of teaching experience, more than $29 \%$ of them have been teaching for 20 years, and more than $45 \%$ of them have attended related training on assessment.

The following is presented the designed Project Assessment Rubric that was used in this research activity. 


\section{Project-Based Assessment Rubric}

Student's name:

Title of Project:

Directions:

1. This rubric consists of three parts.

2. The scores of option consists of:

Strongly Accurate $(\mathrm{SA})=4$

Accurate $(A)=3$

Inaccurate $(I A)=2$

Strongly inaccurate $(\mathrm{SIA})=1$

3. Circle the score available in the column.

\begin{tabular}{|l|c|c|c|c|}
\hline Contents based on Critical Instructions & SA & A & IA & SIA \\
\hline Compare (look for similarities \& differences) & 4 & 3 & 2 & 1 \\
\hline Contrast (stress the dissimilarities) & 4 & 3 & 2 & 1 \\
\hline Criticize (stress the deficiencies) & 4 & 3 & 2 & 1 \\
\hline Define (give a concise and accurate definition) & 4 & 3 & 2 & 1 \\
\hline Describe (mention the chief characteristics) & 4 & 3 & 2 & 1 \\
\hline Diagram (provide a drawing, chart or plan) & 4 & 3 & 2 & 1 \\
\hline Discuss (be analytical; give reasons pro and con) & 4 & 3 & 2 & 1 \\
\hline Evaluate (provide both positive \& negative sides of the topic) & 4 & 3 & 2 & 1 \\
\hline Explain (provide the causes) & 4 & 3 & 2 & 1 \\
\hline Illustrate (use examples; a diagram or figure) & 4 & 3 & 2 & 1 \\
\hline Interpret (translate, solve, or comment on your judgment) & 4 & 3 & 2 & 1 \\
\hline Justify (provide the reasons for your conclusions) & 4 & 3 & 2 & 1 \\
\hline List (provide an itemized list) & 4 & 3 & 2 & 1 \\
\hline Outline (organize the answer into main \& subordinate points) & 4 & 3 & 2 & 1 \\
\hline Prove (provide factual evidence, logical or mathematical proof) & 4 & 3 & 2 & 1 \\
\hline Relate (show the connection between the things in the question) & 4 & 3 & 2 & 1 \\
\hline Review (provide a summary, usually a critical one) & 4 & 3 & 2 & 1 \\
\hline Summarize (provide a summary, usually without comment/criticism) & 4 & 3 & 2 & 1 \\
\hline Trace (describe the progress of some historical event) & 4 & 3 & 2 & 1 \\
\hline
\end{tabular}

\begin{tabular}{|c|c|c|c|c|}
\hline Organization (0) & SA & A & IA & SIA \\
\hline Topic sentence & 4 & 3 & 2 & 1 \\
\hline Supporting sentences & 4 & 3 & 2 & 1 \\
\hline A concluding sentence & 4 & 3 & 2 & 1 \\
\hline Unity & 4 & 3 & 2 & 1 \\
\hline Cohesion & 4 & 3 & 2 & 1 \\
\hline Coherence & 4 & 3 & 2 & 1 \\
\hline Introductory paragraph & 4 & 3 & 2 & 1 \\
\hline Body (main paragraph) & 4 & 3 & 2 & 1 \\
\hline A Concluding paragraph & 4 & 3 & 2 & 1 \\
\hline
\end{tabular}

\begin{tabular}{|c|c|c|c|c|}
\hline Language (L) & SA & A & IA & SIA \\
\hline Subject-verb agreement & 4 & 3 & 2 & 1 \\
\hline Tense-form & 4 & 3 & 2 & 1 \\
\hline Subordination & 4 & 3 & 2 & 1 \\
\hline Verbal & 4 & 3 & 2 & 1 \\
\hline Pronoun - reference & 4 & 3 & 2 & 1 \\
\hline Word form & 4 & 3 & 2 & 1 \\
\hline Word order & 4 & 3 & 2 & 1 \\
\hline Parallel structure & 4 & 3 & 2 & 1 \\
\hline Unnecessary repetition & 4 & 3 & 2 & 1 \\
\hline Correct usage & 4 & 3 & 2 & 1 \\
\hline Punctuation \& capitalization & 4 & 3 & 2 & 1 \\
\hline
\end{tabular}

Score: $\mathrm{C}+\mathrm{O}+\mathrm{L}=$

Rater 


\section{Findings and Discussion}

Table 1. Perceptions toward factors of accuracy on COL rubric

\begin{tabular}{|c|l|c|c|c|}
\hline NO & ASPECTS & MEAN & SD & INTERPRETATION \\
\hline 1 & evaluation format & 3.92 & 0.60 & high \\
\hline 2 & critical instructions \& activities to do & 4.02 & 0.73 & high \\
\hline 3 & paragraph \& essay organization & 3.96 & 0.81 & high \\
\hline 4 & language & 4.10 & 0.76 & high \\
\hline 5 & holistic & 3.85 & 0.74 & high \\
\hline 6 & analitic & 3.94 & 0.63 & high \\
\hline 7 & interval & 3.84 & 0.85 & high \\
\hline 8 & Capitalization \& punctuation (mechanic) & 4.05 & 0.61 & high \\
\hline
\end{tabular}

The teaching staff of FKIPUR, FKIPUIR, FTUIN Susqa, and state secondary schools in Pekanbaru, Indonesia had a high level of perception towards the project-based assessment rubric containing COL. This was due to the fact that all constructs available in project-based assessment rubric showed a high level of interpretation on evaluation format (3.92), critical instructions \& activities to do (4.02), paragraph \& essay organization (3.96), language (4.10), holistic (3.85), analytic (3.94), interval (3.84), and capitalization \& punctuation (mechanic) (4.05). Based on this phenomenon, it can be interpreted that they agreed if this rubric is eligible, suitable, feasible, proper, and fit enough with their needs for the evaluation and measurement of students' projects viewed from the factor of accuracy.

However, Reddy and Andrade (2010:435) concluded that a rubric is not only eligible, suitable, feasible, proper, and fit enough to meet the needs of raters but it also needs the factors of validity and reliability. One of the ways to identify the validity and reliability of a rubric is by putting a special attention to the aspects of language which must be simply understood but depends on raters' interpretation of student performance. In addition, Reddy (2007:14) stated that "rubrics assisted feedback and assessment processes enhance achievement levels; develop positive perceptions about grading; increase motivation; and enhance self-regulated learning behavior".

In line with the above points, Atkinson \& Lim (2013:651) reported about students and teachers perceptions on rubrics. For students, the majority of students preferred a rubric. The students concluded that through a rubric they would be able "to identify what to do, what to achieve or had been achieved, and what to improve". Meanwhile, teachers perceived that rubrics can shorten time consuming for correction along with feedback up to $40 \%$. On the other hand, Moni \& Moni (2008:47) stated that a clear exposure to students on the benefits of rubrics is really important. The reason for this is that the majority of students are eager to be evaluated and measured through a "newly simple, fair, appropriate, constructed assessment rubric". This idea is supported by Eshun \& Poku (2013) who concluded that in terms of studiobased learning, $86 \%$ of the students had a positive perception on the use of rubric for its support in learning process; $46 \%$ asked for training on the implementation of that kind of rubric, and other $89 \%$ believed that rubric made them have a good acquaintance to each other, but Andrade and Ying (2005) reported that students not only had a positive perception towards rubrics but they also agreed that rubrics supported their academic performance in the contexts of 'efforts, product, higher grade, and ready for assignments.' Lim and Marie (2013) concluded that rubrics helped students reach teaching objectives, withdrew their oral production performances, and justified the grades given to them but it was still required to evaluate the appropriateness and effectiveness of rubric as a grading method for oral production assessments. Finally, Laura (2010) concluded in her research that pre-service teachers used rubrics not only during their teaching practice exercise (as students-teachers) but also in their own real teaching.

Table 2. Perceptions toward factors of practicality on COL Rubric

\begin{tabular}{|c|l|c|c|c|}
\hline NO & ASPECTS & MEAN & SD & INTERPRETATION \\
\hline 1 & rubric format & 3.54 & 0.81 & moderate \\
\hline 2 & critical instructions \& activities to do & 3.48 & 0.77 & moderate \\
\hline 3 & paragraph \& essay organization & 3.78 & 0.72 & high \\
\hline 4 & language & 3.78 & 0.72 & high \\
\hline 5 & holistic & 3.77 & 0.76 & high \\
\hline 6 & analitic & 3.69 & 0.80 & high \\
\hline 7 & interval & 3.66 & 0.81 & moderate \\
\hline 8 & capitalization \& punctuation (mechanic) & 4.00 & 0.54 & high \\
\hline
\end{tabular}


However, the perception of the teaching staff of FKIPUR, FKIPUIR, FTUIN Susqa, and state secondary schools towards the project-based assessment rubric containing $\mathrm{COL}$ viewed from the factor of practicalities showed that such constructs as rubric format (3.54), critical instructions \& activities to do (3.48), and interval (3.66) were in moderate level. Meanwhile, others including paragraph \& essay organization (3.78), language (3.78), holistic (3.77), analytic (3.69), and capitalization \& punctuation (mechanic) (4.00) were in high level.

Table 3. Perceptions toward factors of accuracy and practicality on COL rubric based on focus group discussion

\begin{tabular}{|c|l|c|c|}
\hline NO & ASPECTS & F & $\%$ \\
\hline 1 & Aspects of Content should be focused on genres. & 35 & 46.7 \\
\hline 2 & Aspects of Organization should be simplified. & 48 & 64.0 \\
\hline 3 & Aspects of Language should not need to be so detail. & 65 & 86.6 \\
\hline 4 & Aspects of content need to be simplified. & 55 & 73.3 \\
\hline 5 & Aspects of organization have already met the criteria. & 58 & 77.3 \\
\hline 6 & Aspects of language may be added or developed by the rater. & 63 & 84 \\
\hline 7 & Aspects of capitalization \& punctuation (mechanic) need to be expanded (unlimited). & 67 & 89.3 \\
\hline
\end{tabular}

Furthermore, in terms of the perspectives of knowledge, attitude, and skill of the teaching staff through focus group discussion program (Krueger, 1994) showed the following results. In the factor of accuracy, $46.7 \%$ of the sample respondents concluded that the aspect of content should be more emphasized on genres, $64 \%$ proposed that the aspect of organization should be simplified, and $86.6 \%$ expected that the aspect of language should be in macro skills. In the factor of practicality, $73.3 \%$ expected that the aspect of content (critical instructions \& activities to do) should be much simpler; and $77.3 \%$ concluded that the aspect of organization is precisely adequate. However, $84 \%$ agreed that the aspect of language should be free to be developed by the staff themselves, and $89.3 \%$ proposed that the constructs of capitalization \& punctuation (mechanic) should be exposed to all parts of writing mechanics.

Finally, hypothesis testing found that null hypothesis $(\mathrm{Ho})$ was accepted. In other words, there was no significant difference of the perception of the teaching staff of FKIPUR, FKIPUIR, FTUIN Susqa, and state secondary schools toward the project-based assessment rubric containing COL based on the variables of institution $(F=2.78$; Sig $=0.15)$, fields of study $(F=2.48 ; \mathrm{Sig}=0.20)$, academic qualification $(F=2.31$; $\mathrm{Sig}=0.29)$, teaching experience $(\mathrm{F}$ 1.35; $\mathrm{Sig}=$ $0.43)$, and training $(F=2.26 ; \mathrm{Sig}=0.39)$.

\section{Implications and Recommendations}

This study has implications for the teaching staff of FKIPUR, FKIPUIR, FTUIN Susqa, and state secondary schools toward the project-based assessment rubric containing COL. In the factor of accuracy, it is clearly found that they have a high level of perceptions toward all constructs included in the aspects of content, organization, and language. This is probably because of such variables as $77 \%$ of them are in the field of English education, $45 \%$ of them have attended related training on assessment, and $29 \%$ of them have 20 years of teaching experience. As a result, they are so familiar with each construct available in that rubric and perceived that all constructs are accurate enough for the purpose of evaluation and measurement. However, they have a moderate level of perceptions on the constructs of rubric format, critical instructions \& activities to do, and interval in the factor of practicality. This is probably due to the following reasons. Rubric format contains various constructs to be evaluated and measured; and of course, it needs training to use it. Critical instructions \& activities to do get involve so many operational verbs so that it needs time-consuming as well as concentration to choose on. Interval perhaps it is relatively new to them since they are used to using holistic scale rather than analytic scale.

In the context of perspectives of knowledge, attitude, and skill, the teaching staff of FKIPUR, FKIPUIR, FTUIN Susqa, and state secondary schools proposed the following things. Firstly, the aspect of content should be more emphasized on genres. This is due to the fact that $51 \%$ of them are teaching at secondary schools in which the teaching of English is focused on genres. Depdiknas, (2008) and Kemendikbud, (2013) stated that language skills and language contents are taught through genres consisting of narrative, procedure, report, recount, news item, various short functional texts along with linguistic features. Secondly, the aspect of organization should be simplified. This can be interpreted that they prefer not to assess the organization of the project in detail but the message is easily understood. Last but not least, the aspect of language should be in macro skills. This is probably due to the fact that they prefer the linguistic features are structurally correct rather than grammatically correct, and they are accustomed to assess students' papers 
holistically. In conclusions, this research recommends that the teaching staff of FKIPUR, FKIPUIR, FTUIN Susqa, and state secondary schools put more emphasys on language contents and writing mechanic as well since these two aspects are the major problems for Indonesian students. This is due to the fact that language contents containing of rules of English structure and grammar are the heart of that language itself even english is still a foreign language in Indonesia. To support this, the teaching staff of FKIPUR, FKIPUIR, FTUIN Susqa, and state secondary schools are encouraged to review more about the concepts of paper writing, to train developing assessment rubrics, and to revise the mechanism of teaching-learning process, particularly on the writing skills related to project-based activities that certainly involves rubrics.

\section{Acknowledgements}

My special thanks are given to firstly, Prof. Dr. H. M. Nur Mustafa, M.Pd, Dean of the Faculty of Education and Teacher Training (FKIP) University of Riau, Indonesia for his support of the research activity. Secondly, colleagues of Learning Psychology Department of FKIP University of Riau, Indonesia for their roles as partners in focus group discussion. Thirdly, those who were taken as the sample of this research for the time to complete the questionnaires. Finally, my grateful thanks also go to those who have given valuable contributions for the accomplishment of this research.

\section{References}

Andrade, H, and Ying, D. (2005). Student perspectives on rubric-referenced assessment. Practical Assessment, Research \& Evaluation Journal. Volume 10 Number 3, April 2005. ISSN 1531-7714.

Ariev, R. P. (2005). A theoretical model for the authentic assessment of teaching.PAREonline.net, 10(2).Retrieved on Jan 20, 2014 from http://PAREonline.net

Arikunto, S. (2010). Prosedur Penelitian. Suatu Pendekatan Praktik. (The Procedure of Research. A Practical Approach).Jakarta: PT Aneka Cipta.

Atkinson, D. \& Lim, L. S. (2013). Improving assessment processes in Higher Education: Student and teacher perceptions of the effectiveness of a rubric embedded in a LMS. Australasian Journal of Educational Technology, 2013, 29(5).

Bernhardt, L.V. (2014). Education for the Future Initiative. http://eff.csuchico.eduC Education for the Future, Chico, CA (http://eff. csuchico.edu) Page 1 of 14.(Retrieved Dec 20, 2014).

Birgin, O., \& Baki, A. (2009). An investigation of primary school teachers' proficiency perceptions about measurement and assessment methods: the case of Turkey. Procedia Social and Behavioral Sciences, 1, 681-685. Retrieved December 10, 2013, from http://www.sciendirect.com

Brooks, V. (2002). Assessment in Secondary Schools: The new teacher's guide o monitoring, assessment, recording, reporting and accountability. Philadelphia: Open University Press.

Brown, H. D. (2004). Language Assessment: principles and classroom practices. New York: Pearson Education Inc.

Callaghan, M. \& Rothery, J. (1988).Teaching factual writing: A genre-based approach. Erskineville, NSW: Metropolitan East Disadvantaged School Program.

Creswell, W.J. (2005).Educational Research. Second Edition. New Jersey: Pearson. Merrill Prentice Hall.

Crooks, (2011). Assessment for learning in the accountability era: New Zealand. Studies in Educational Evaluation, 37 (2011): 71-77. Science Direct. Retrieved July 20, 2012, from www.elsevier.com/stueduc

Depdiknas. (2003). Hasil need assessment guru SMP. Jakarta: Direktorat Pendidikan LanjutanPertama, Departemen Pendidikan Nasional. (Results of needs assessment of Secondary School Teachers. Jakarta: Directorate of first continuing Education, Department of National Education).

Depdiknas, (2008). Rancangan penilaian hasil belajar. Jakarta: Dirjen Manajemen Pendidikan Dasar dan Menengah. Direktorat Pembinaan Sekolah Menengah Atas. (The Design of learning achievement. Jakarta: Directorate General for Management of Primary and Secondary Education. Directorate of Secondary Education.).

Dickens \& Germanie, (1992). Evaluation.New York: Oxford University Press.

Erman, S \& Yaya, S. (1990). Kriteria penentuan hasil belajar. (Determining learning achievement criteria). Bandung: Wijaya Kusuma.

Eshun, F. Eric \& Poku, O. Patrick, (2013). Design Students Perspectives on Assessment Rubric in Studio-Based Learning. Journal of University Teaching \& Learning Practice. Volume 10.Issue 1.Article 8.http://ro.uow.edu.auljutlp.

Fadly Azhar, (2013). Content, organization, and language (COL): A current, integrated rubric for the correction of writing skill. Prosiding Semirata BKS PTN Wilayah Barat 2013. Pontianak: STAIN Pontianak Press. (Proceeding. An annual Seminar, Conference in Cooperation of Indonesian Western Universities. Pontianak: State Islamic Institute, August, 2013).

Fernandes, H.J.X. (1984). Testing and measurement.Jakarta: National Educational Planning, Evaluation and Curriculum Development. Hughes, A. (2003). Testing for Language Teachers. Second Edition. Cambridge: Cambridge University Press.

Hutchinson, C. \& Young, M. (2011). Assessment for learning in the accountability era: Empirical evidence from Scotland. Studies in Educational Evaluation, 37: 62-70.

IELTS Practice Topics, (2006). Posted on November 6, 2006. 
Kemendikbud, (2013). Materi pelatihan guru implementasi Kurikulum 2013. Jakarta: Kementerian Pendidikan dan Kebudayaan. (Ministry of culture and Education, 2013.Training module for teachers in the implementation of Curriculum 2013. Jakarta: Ministry of Culture and Education.)

Krueger, R.A. (1994). Focus groups: A practical guide for applied research. Newbury Park, CA: Sage Publication.

Laura, K.R. (2010). Rubric-referenced assessment in teacher preparation: An opportunity to learn by using. Practical Assessment, Research \& Evaluation. Volume 15, Number 8, May 2010. Retrieved on (20.01.2015).

Lim, J. \& Marie, A. (2013). Rubric-referenced oral production assessments: perceptions on the use and actual use of rubrics in oral production assessments of high school students of St. Scholastica's College, Manila. Language Testing in Asia. 3:4 Page 2 of 14 http://www.languagetestingasia.com/content/3/1/4

McMillan, H. J. (2004). Classroom Assessment: Principles and Practice for Effective Instruction. Third Edition. USA: Pearson Education.

Media Informasi Online Stikom. (2003). In Edy Supriyadi. (2007). Penilaian kelas sebagai mekanisme umpan balik untuk meningkatkan mutu pembelajaran. (Classroom assessment as a feedback mechanism in raising the quality of education). http://www.smunetcom(07.08.11).

Mertler, A.C. (2001). Designing scoring rubrics for your classroom. http://PAREonline.net (20.06.2014).

Moni, W. R. \& Moni, B. K. (2008). Student perceptions and use of an assessment rubric for a group concept map in physiology. Advances in Physiology Education. Retrieved from: http://www.the-aps.org/ (16.1.2015)

Moskal, M.B., \& Jon, L.A. (2000).Scoring Rubrics development: validity and reliability. Retrieved January 12, 2014, from http://PARE online.net

O'Malley, M.J \& Pierce, V.L. (1996). Authentic Assessment for English Language Learners. New York: Addison-Wesley Publishing Company.

Oshima, A. \& Hogue, A. (1999). Writing Academic English. Third Edition. Longman: Pearson Education.

Popham, W.J. (1995). Classroom Assessment: What teachers need to know. Boston: Pearson Education Inc.

Reddy, Y. M. \& Andrade, H. (2010). A review of rubric use in higher education. Assessment \& Evaluation in Higher Education. Vol. 35, No. 4, July 2010, 435-448. Taylor \& Francis.(Retrieved from: http://www.informaworld.com.pdf.(17.1.2015).

Reddy,Y. Malini. (2007). Effect of Rubrics on Enhancement of Student Learning. Retrieved from: http://www.educatejournal.org/ (17.1.2015).

Schlegel, N. (1992). Research and Study Skills Guide for Senior Students. 3rdEdition.Burwood Victoria: Beri Publishing.

Shohamy, E. (1985). A Practical handbook in language testing for the second language teacher. Israel: Tel- Aviv University.

Stanley, N. C. (1983). Building skills for the TOEFL. Boston: Heinle and Heinle Publishers Inc.

Sugiyono, (2011). Statistika untuk Penelitian. (Statistics for Research).Bandung: Alfabeta.

Tierney, R., \& Marielle, S. (2004). What's wrong with rubrics: focusing on the consistency of performance criteria across scale levels. Retrieved September 15, 2013, from http://PAREonline.net

Weigle, S.C. (2002). Assessing writing. Cambridge: Cambridge University Press. 